\title{
Retraction Note to: Modeling ductile to brittle transition temperature of functionally graded steels by fuzzy logic
}

\author{
Ali Nazari ${ }^{1, *}$ and Amir Ali Milani ${ }^{1}$ \\ ${ }^{1}$ Department of Materials Science and Engineering, Saveh Branch, Islamic Azad University, Saveh, Iran
}

\begin{abstract}
Published online:
7 July 2020

(C) Springer Science+Business

Media, LLC, part of Springer

Nature 2020
\end{abstract}

Retraction Note to: J Mater Sci (2011) 46:6007-6017

https://doi.org/10.1007/s10853-011-5563-z

The Editor-in-Chief has retracted this article [1] because it significantly overlaps with a large number that were under consideration at the same time, including [2], and previously published articles [3-6]. Additionally, the article shows evidence of peer review manipulation. The authors have not responded to any correspondence regarding this retraction.

\section{References}

[1] Nazari A, Milani AA (2011) Modeling ductile to brittle transition temperature of functionally graded steels by fuzzy logic. J Mater Sci 46:6007-6017. https://doi.org/10.1007/s10 853-011-5563-z

[2] Nazari A, Milani AA, Khalaj G (2012) Modeling ductile to brittle transition temperature of functionally graded steels by ANFIS. Appl Math Model 36(8):3903-3915. https://doi.org/ 10.1016/j.apm.2011.11.032

[3] Nazari A, Milani AA, Zakeri M (2011) Modeling ductile to brittle transition temperature of functionally graded steels by artificial neural networks. Comput Mater Sci 50(7):2028-2037. https://doi.org/10.1016/j.commatsci.2011.0 2.003

[4] Milani AA, Nazari A (2012) RETRACTED: Modeling ductile-to-brittle transition temperature of functionally graded steels by gene expression programming. Int J Damage Mech 21(4):465-492. https://doi.org/10.1177/1056789511406561

[5] Nazari A, Milani AA (2012) RETRACTED: Ductile to brittle transition temperature of functionally graded steels. Int $\mathrm{J}$ Damage Mech 21(2):191-205. https://doi.org/10.1177/ 1056789511398270

The original article can be found online at https://doi.org/10.1007/s10853-011-5563-z.

Address correspondence to E-mail: alinazari84@aut.ac.ir 
[6] Nazari A, Milani AA (2011) Ductile to brittle transition temperature of functionally graded steels with crack arrester configuration. Mater Sci Eng: A 528(10-11):3854-3859. h ttps://doi.org/10.1016/j.msea.2011.01.105
Publisher's Note Springer Nature remains neutral with regard to jurisdictional claims in published maps and institutional affiliations. 